\title{
Çıplak Köklü Kokulu Ardıç (Juniperus foetidissima Wild.) Fidanlarında Su Potansiyeli Bileşenlerinde Oluşan Dönemsel Değişimler
}

\author{
İbrahim ARSLAN ${ }^{1},{ }^{*}$ Ayşe DELİGÖZ ${ }^{1}$ \\ ${ }^{1}$ Süleyman Demirel Üniversitesi, Orman Fakültesi, Orman Müh.Böl., Isparta,Türkiye \\ *Sorumlu yazar: aysedeligoz@sdu.edu.tr
}

Geliş Tarihi:25.08.2015

\begin{abstract}
Özet
Bu çalışmada, 1+0 yaşındaki çıplak köklü kokulu ardıç (Juniperus foetidissima Wild.) fidanlarında su potansiyeli bileşenlerinde meydana gelen dönemsel değişimler incelenmiştir. Ekim 2011 tarihinden Nisan 2012 tarihine kadar dört haftalık aralıklarla Eğirdir Orman Fidanlığı'ndan fidan sökümü gerçekleştirilmiştir. Her bir ölçüm döneminde basınç-hacim eğrisi tekniği yardımıyla su potansiyeli bileşenleri ölçülmüş ve solma noktasındaki osmotik potansiyel $\left(\psi_{\pi \mathrm{TLP}}\right)$, doygun haldeki osmotik potansiyel $\left(\psi_{\pi 100}\right)$, solma noktasındaki serbest su içeriği $\left(\mathrm{FWC}_{\mathrm{TLP}}\right)$, solma noktasındaki nispi su içeriği $\left(\mathrm{RWC}_{\mathrm{TLP}}\right)$, birim kuru ağırlık başına düşen simplastik su miktarı $\left(\mathrm{V}_{0} / \mathrm{DW}\right)$, apoplastik su fraksiyonu $\left(\mathrm{V}_{\mathrm{a}} / \mathrm{V}_{\mathrm{T}}\right)$ ve kuru ağırlık oranı (DWF) belirlenmiştir. Çalışma sonuçlarına göre sadece solma noktasındaki osmotik potansiyelinde mevsimsel bir değişim görülmüştür. Solma noktasındaki osmotik potansiyel ekim ayından itibaren yavaş yavaş azalmış ve en düşük değerlere aralık ayında ulaştıktan sonra tekrar artarak nisan ayında yüksek değerler almıştır. Diğer su potansiyeli bileşenlerinde $\left(\psi_{\pi 100}, \mathrm{FWC}_{\mathrm{TLP}}, \mathrm{RWC}_{\mathrm{TLP}}\right.$, $\mathrm{V}_{0} / \mathrm{DW}, \quad \mathrm{V}_{\mathrm{a}} / \mathrm{V}_{\mathrm{T}}$ and $\left.\mathrm{DWF}\right)$ ölçüm dönemleri arasında istatiksel olarak anlamlı bir farklılık belirlenmemiştir. Aralık, ocak ve şubat döneminde sökülen Kokulu ardıç fidanlarının stres dayanıklılığı, ekim, kasım, mart veya nisan ayında sökülen fidanlardan daha yüksektir. Eğirdir Orman Fidanlığı koşullarında Kokulu ardıç fidanları için güvenli söküm dönemi aralık sonu- şubat sonu dönem olarak tespit edilmesine karşın, söküm veya dikim için hava koşulları uygun değil ise, söküm zamanının kasım sonuna kadar öne veya mart sonuna kadar ileriye çekilebileceği sonucuna varılmıştır.
\end{abstract}

Anahtar kelimeler: Juniperus foetidissima, Basınç-Hacim eğrisi, Osmotik potansiyel, Söküm zamanı

\section{Seasonal changes in water potential components of bareroot Stinking juniper (Juniperus foetidisima Wild.) Seedlings}

\begin{abstract}
In this study, seasonal changes in water potential components on $1+0$ year old bareroot Stinking juniper (Juniperus foetidissima Wild.) seedlings were examined. Seedlings were lifted from Eğirdir Forest Nursery four weeks apart from October 2011 to April 2012. In each sampling period, water potential components were measured by the pressure - volume $(\mathrm{P}-\mathrm{V})$ curve technique and osmotic potential at full turgor $\left(\psi_{\pi 100}\right)$, osmotic potential at turgor loss point $\left(\psi_{\pi \mathrm{TLP}}\right)$, free water content at turgor loss point $\left(\mathrm{FWC}_{\mathrm{TLP}}\right)$, relative water content at turgor loss point (RWC $\left.\mathrm{RLP}_{\mathrm{T}}\right)$, symplastic water at saturated point per dry weight of the shoot $\left(\mathrm{V}_{0} / \mathrm{DW}\right)$, apoplastic water fraction $\left(\mathrm{V}_{\mathrm{a}} / \mathrm{V}_{\mathrm{T}}\right)$ and dry weight fraction (DWF) were determined. According to the results of this study, only osmotic potential at turgor loss point showed a seasonal change. $\psi_{\pi T L P}$ value decreased gradually from October and after reaching the lowest values in December, it increased again and reached high values in April. The differences among lifting dates were not significant in other water potential component $\left(\psi_{\pi 100}, \mathrm{FWC}_{\mathrm{TLP}}, \mathrm{RWC}\right.$ TLP, $\mathrm{V}_{0} / \mathrm{DW}, \mathrm{V}_{\mathrm{a}} / \mathrm{V}_{\mathrm{T}}$ and $\left.\mathrm{DWF}\right)$. Bareroot Stinking juniper seedlings lifted in December, January and February have greater stress resistance than seedlings lifted in October, November, March or April. In Eğirdir forest nursery, although the safe period for lifting are late December to late February, it was concluded that if weather conditions are adverse for lifting or planting, lifting period should begin early until late November or delay until late March.
\end{abstract}

Keywords: Juniperus foetidissima, Pressure - Volume curve, Osmotic potential, Lifting time

\section{Giriş}

Türkiye ormancılığı, ana ve geçiş iklim tiplerinin çeşitliliği ve yayılış gösteren türlerin zenginliği ile geniş varyasyonlara sahiptir (Dirik, 1991). Ardıç türleri bu anlamda üzerinde durulması gereken en önemli odunsu taksonlardandır. Ardıç sı̆̆ fakir, taşlık-kayalık alanlarda yetișebilen, kanaatkâr bir ağaç türüdür. Uzun yıllardan beri, değerli odunu ve denetimsiz aşırı otlatma baskısı nedeniyle, çok tahribata uğramıştır (Eler ve Çetin, 2006). Resmi kayıtlarda Türkiye ardıç ormanı varlı̆̆ının 1.1 milyon hektar olduğu ve bu alanların 
\%92' sinin ise bozuk olduğu belirtilmektedir (Anonim, 1987). Türkiye ardıç ormanlarının $\% 82$ 'sini boylu ardiç, \% 15'ini kokulu ardiç ve \% 3'lük kısmını ise diğer ardıç türleri oluşturmaktadır (Gültekin, 2007). Kokulu ardıç türü 35 metreye kadar boylanabilen, 4 metreye kadar çap yapabilen, çok uzun ömürlü (2000 y1l), piramidal tepe yapısına sahip, düzgün gövdeli bir orman ağacıdır (Gültekin ve Gültekin, 2007). Güneydoğu ve Doğu Anadolu hariç ülkemizin tamamına yakınında, deniz ikliminden kaçınarak 800 metre ile alpin zon arasında yayılış göstermektedir. Yer yer bireysel olarak 500 metreye kadar inebilmektedir. Orman kurduğu alanların tipik özellikleri; karasal iklim özellikleri göstermesi, yıllık ortalama yağış miktarının 400-600 mm arasında olmas1 ve ekstrem toprak ve iklim özelliklerine sahip olmasıdır. Gölgeli bakılarda, daha az güneşlenen çukurluk alanlarda, vadi içlerinde, derin topraklı sahalarda, yoğun kar tutan alanlarda, şiddetli soğuğun etkili olduğu ortamlarda ve taban arazilerde yayılış gösterir. Kokulu ardıç türünün yayılış gösterdiği alanların yağış tipi çoğunlukla kardır (Gültekin ve Gültekin, 2006).

Kokulu ardıç türünün tohumunun çimlenme engelinin aşılmasıyla kitlesel fidan üretim çalışmalarına başlanılmıştır. Bunun sonucu olarak da, son yillarda yapilan ağaçlandırma çalışmalarında tercih edilen türler arasında yerini almıştır (Gültekin ve Gültekin, 2007). Ağaçlandırma çalışmalarının başarısında; toprak ve çevreyle ilgili şartların yanı sıra, tohum toplamadan başlayıp fidan yetiştirme, söküm, ambalajlama, dikim ve ağaçlandırma sahalarındaki bakıma kadar olan süreç içindeki çeşitli faktörlerin etkili olduğu bildirilmektedir (Tetik,1995).

Ağaçlandırma çalışmalarında uygun orijin ve kaliteli fidan kullanmak, başarı oranını yükseltmektedir (Şimşek 1987). Dikim başarısı için, genetik ve morfolojik özellikler bakımından kaliteli fidanların, fizyolojik özelliklerce de kaliteli oldukları bir zaman diliminde sökülmesi önkoşuldur (Genç ve Yahyaoğlu, 2007). Ancak, her yil fizyolojik bakımdan zayıf olan milyonlarca orman ağacı fidanı kültür sahalarına dikilmektedir (Yahyaoğlu, 1987). En uygun söküm tarihi, orijinden orijine, türden türe, fidanlıktan fidanlığa, yıldan yıla ve uygulanan yetiştirme tekniklerine bağlı olarak değişmektedir. Dolayısıyla, fizyolojik özellikler açısından kaliteli fidanların elde edilmesine yönelik, türler bazında uygun söküm tarihlerinin belirlenmesi için gerekli araştırmalar yapılmalıdır.

Fidan kalite sinıflamasında önceleri morfolojik özellikler üzerinde durulmuş, ancak son zamanlarda yapılan çalışmalarda fizyolojik özellikler de kalite sinıflamasındaki değerlendirmelerde yerini almıştır (Deligöz, 2007). Fizyolojik özelliklerden bitki su potansiyeli bileşenlerinden olan solma noktasındaki su potansiyeli, dikim şokunun atlatılmasında son derece önemli bir değerdir (Ritchie, 1984; Yahyaoğlu, 1987; Genç, 1992; Dirik, 1999). Bu kritik değer, yıl içinde mevsimsel olarak değişiklik göstermektedir. Fidanların gerçek dormansi durumunda karbonhidrat içeriği yükselirken, turgor halini koruma dirençleri artmakta, yani sürekli solma noktasındaki su potansiyeli en düşük değerini almaktadır. Yapılan birçok araştırmada, sürgün dokularına ait solma noktasındaki su potansiyeli değeri, fidanlar için tazelik sınırı kabul edilmiştir (Ritchie, 1984; Yahyaoğlu, 1987; Semerci, 1994). Sürekli solma noktasındaki su potansiyeli, fidanların tazeliğini, düşük sıcaklıklara ve kuraklık stresine dayanıklılıklarını ortaya koyduğu için onların sökülebilirliğine karar vermede temel kıstas olarak kabul edilmektedir (Genç ve Yahyaoğlu, 2007). Bu nedenle, su potansiyeli bileşenlerinin özellikle de sürekli solma noktasindaki su potansiyelinin mevsimsel değişiminin belirlenmesi, hem fidanın fizyolojik kalitesinin tespiti, hem de uygun söküm zamanlarının belirlenmesi açısından oldukça önemlidir. Bu çalışmada, ülkemizde son yıllarda kitlesel fidan üretimi gerçekleştirilen ve ağaçlandırma çalışmalarına konu edilen çıplak köklü kokulu ardıç fidanlarında su potansiyeli ve bileşenlerinde oluşan mevsimsel değişim araştırılmış ve türün uygun söküm-dikim zamanına ilişkin önerilerde bulunulmuştur. 


\section{Materyal Ve Yöntem}

\section{Materyal}

Çalışma, Eğirdir Orman Fidanlık Müdürlüğ̈̈'nde ( $37^{\circ} 53^{\prime}$ kuzey enlemi; $30^{\circ}$ 52' doğu boylamı; ortalama $926 \mathrm{~m}$ rakımda) gerçekleştirilmiştir. Araştırma materyali olarak, Eğirdir Orman Fidanlı̆̆ında yetiştirilen Isparta-Belceğiz orijinli $1+0$ yaşındaki çıplak köklü kokulu ardıç (Juniperus foetidissima Wild.) fidanlar1 kullanılmıștır. Tohum ekimi, fidanlığın 13 nolu parseline çizgi ekimi yöntemiyle 13
Kasım 2010 tarihinde gerçekleștirilmiștir. Çalışmanın yürütüldüğü ekim parselinin toprak türü kumlu balçık tekstüründe olup, $\mathrm{pH} 8.10$, organik madde içeriği $\% 1.87$ ve toplam kireç miktarı \%13.60'dır (Anonim, 2010). Fidanlıkta Akdeniz iklimi ile karasal iklim hâkim olmakla birlikte, karasal iklimin etkisi daha fazla hissedilmektedir. Çalışmanın yürütüldüğü dönemlere ait iklim verileri Şekil 1'de verilmiştir.

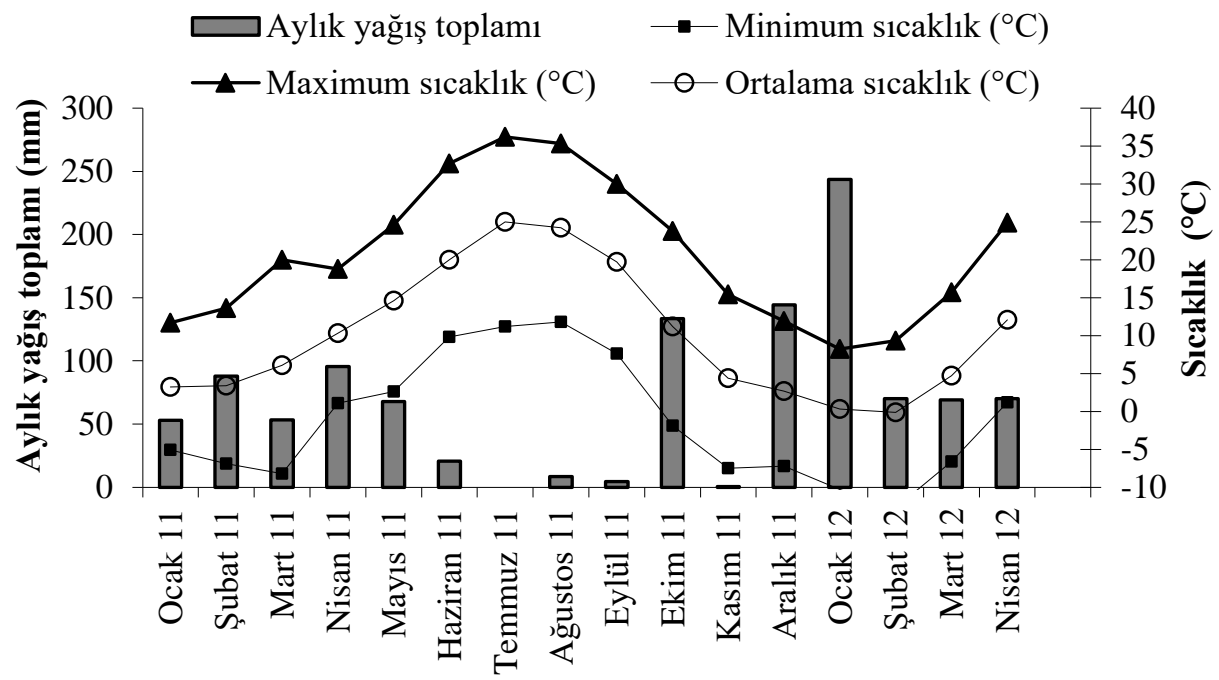

Şekil 1. Çalışma periyodu süresince Eğirdir Orman Fidanlığına ait iklim verileri (Anonim, 2012)

\section{Yöntem}

Çalışmada, $1+0$ yaşındaki kokulu ardıç fidanlarında, 2011 yılı ekim ayından 2012 yılı nisan ayına kadar her ayın yaklaşık sonuna doğru fidan sökümleri yapılmıştır. Sökülen fidanlar, açık hava şartlarından etkilenmemesi için nemli telis ile sarılmış ve polietilen torbalara yerleştirilerek aynı gün içinde Süleyman Demirel Üniversitesi Orman Fakültesi Bitki yetiștirme laboratuvarına getirilmiştir. Laboratuvara getirilen fidanlarda seleksiyon yapıldıktan sonra, sağlıklı olan 10 adet fidan ölçüm çalışmaları için ayrılmıştır. Her ay için seçilen 10 adet fidanın her biri kök boğazından kesilmiş ve gövde kısımları, toprak ve bitki artıklarından temizlenmesi için çeşme suyunda yıkanmıştır. Yıkama işlemi biten sürgün örnekleri, havlu kâğıt yardımıyla iyice kurulanmış ve her birinin taze ağırlıkları $(\mathrm{TaA}) \quad 0.0001 \mathrm{~g}$ hassasiyetindeki terazide ölçülmüş ve numara verilerek etiketlenmiş̧ir. Etiketlenen sürgün örnekleri hemen saf su içine koyulup, oda sicaklığında karanlık bir ortamda, tam doygun hale getirmek için 24 saat bekletilmiş ve sonrasında doygun haldeki ağırlıkları (DoA) tespit edilmiștir. Ölçüm yapılacak sürgün örneğinin kesim yerinden itibaren 1 cm'lik kısımdaki kabuk soyularak ksilem açığa çıkarılmış ve bitki basınç odasında fidanın su potansiyeli ölçülmüştür. Ölçülen ilk değer $0.15 \mathrm{MPa}$ 'dan daha büyük ise, sürgün örneğinin tam doygun olmadığ 1 kabul edilerek başka bir sürgün örneği ile ölçüm tekrarlanmıştır. İçerisine filtre kağıd1 yerleştirilerek başlangıç ağırlığı $0.0001 \mathrm{~g}$ hassasiyetindeki terazide tartılıp çizelgeye 
kaydedilen plastik tüpçük, doygun olduğunu kabul ettiğimiz örneğin kesim yüzeyine temas edecek şekilde yerleştirilmiştir. Bitki basınç odası cihazının oda basıncı $0.3 \mathrm{MPa}$ arttırılarak, bu basınç kademesinde sürgün örneği 10 dakika bekletilmiştir. 10 dakika sonunda, tüpçük içine yerleştirilen filtre kağıdı yardımıyla toplanan preslenmiş suyun miktarını saptamak için, plastik tüpçük, $0.0001 \mathrm{~g}$ hassasiyetindeki terazide tartılmış ve okunan değer ilgili tabloya kaydedilmiştir. Örneğin özsuyunu kesim yüzeyinden uzaklaştırıp, içsel su gerilimini düzenlenmek amacıyla, oda içindeki basınç ortalama 1.5 MPa düşürülmüş ve iki dakika beklenilmiştir. İki dakika sonunda, oda basınc1, kesim yüzeyinde özsu tekrar görülünceye kadar yavaşça arttırılmıştır. Özsuyun görüldüğü andaki yeni basınç değeri okunmuş ve ikinci değer olarak tablodaki ilgili kısma kaydedilmiştir. Çalışma, 0.3 er MPa'lık basınç kademeleri ile gerektiğinde 25 nokta alınıncaya (bitki su potansiyeli ortalama -4.5 MPa oluncaya) kadar aynı işlemlerle sürdürülmüştür. Ölçüm sonunda, örneğin ölçüm sonu ağırlığı tartılmış (SoA), daha sonra 24 saat $105{ }^{\circ} \mathrm{C}$ de kurutma firıninda bırakılarak, firın kurusu ağırlığı (KuA) belirlenmiştir. Bir koordinat sistemi üzerinde, uygulanan basınç (bar) kademelerinin tersi $(1 / b)$ bar olarak düşey eksene, bunların karşılığında dışarıya preslenen yığılmalı su miktarı da mg cinsinden yatay eksene Excel programında aktarılmış ve basınç-hacim (P$\mathrm{V})$ eğrisi oluşturulmuştur. $\mathrm{Bu}$ eğri yardımıyla, solma noktasındaki osmotik potansiyel $\left(\psi_{\pi T L P}\right)$ ile tam doygun haldeki osmotik potansiyel $\left(\psi_{\pi 100}\right)$ değeri tespit edilmiştir. Diğer su potansiyeli bileşenleri ise aşağıdaki formüller kullanılarak hesaplanmıştır (Genç, 1992; Semerci, 1994; Dirik, 2000).

Solma noktasındaki serbest su içeriği

$\left(\mathrm{FWC}_{\mathrm{TLP}} ; \%\right)=\left[\frac{V o-V e}{V o}\right] \times 100$

Sürgündeki toplam su $\left(\mathrm{V}_{\mathrm{t}}\right)=D o A-K u A$

Solma noktasındaki nisbi su içeriği $\left(\mathrm{RWC}_{\mathrm{TLP}} ; \%\right)=\left[\frac{V t-V e}{V t}\right] \times 100$
Birim kuru ağırlığa düşen simplastik su oran $1(\mathrm{Vo} / \mathrm{DM})=\frac{V o}{K u A}$

Relatif
$\left[\frac{T a A-K u A}{D o A-K u A}\right] \times 100$

$$
\text { Apoplastik su oranı }=V a / V T
$$

Kuru ağırlık oranı $(\mathrm{DWF})=K u A / D o A$

Ve, dokulardan solma noktasina ulaşıncaya kadar preslenen su miktarını; Va, apoplastik su miktarını; Vo, simplastik su miktarını göstermektedir.

\section{Verilerin Değerlendirilmesi}

Saptanan değerler SPSS For Windows Ver. 17.0 bilgisayar istatistik paket programından yararlanılarak bilgisayar ortamında ayrı ayrı işlenerek değerlendirilmiştir. $\mathrm{Bu}$ bağlamda, su potansiyeli bileşenlerinin tarihsel değişimini ortaya koymak amaciyla her bir bileşen için "varyans analizi" yapılmış ve ölçüm tarihleri arasında istatistik açıdan önemli fark bulunması halinde, homojen tarihleri saptamak maksadiyla "Duncan testi" uygulanmıştır. Oransal değerler, istatistikî analizler öncesi arcsin dönüşümüne tabi tutulmuştur. $\mathrm{Su}$ potansiyeli bileşenleri arasındaki ilişkileri belirlemek amacıyla korelasyon analizi de yapılmıştır.

\section{Bulgular}

Basınç-hacim (P-V) eğrisi yöntemiyle elde ettiğimiz su potansiyeli bileşenlerinden solma noktasindaki osmotik potansiyeline ilişkin varyans analiz sonuçlarına göre, örneklemenin yapıldığ 1 tarihler arasında 0.05 önem düzeyinde önemli bir farklılık bulunmaktadır. Duncan testi sonuçlarına göre, solma noktasındaki osmotik potansiyel $\left(\psi_{\text {TILP }}\right)$ en düşük ortalama değerini (-2.99 MPa) 20 Aralık 2011 tarihinde, en yüksek ortalama değerini (-2.29 MPa) ise 27 Ekim 2012 tarihinde almıştır. Şekil 2'i incelendiği zaman, $\psi_{\pi T L P}$ değerlerinin ekim ayından itibaren azalarak aralık ayında en düşük değerini aldığı, ocak ayından itibaren ise 
yavaş yavaş yükselişe geçtiği görülmektedir. Ayrıca, ocak ayı ile şubat ayı ve kasım ayı ile mart ayı aynı homojen grupta yer almıștır (Şekil 2).

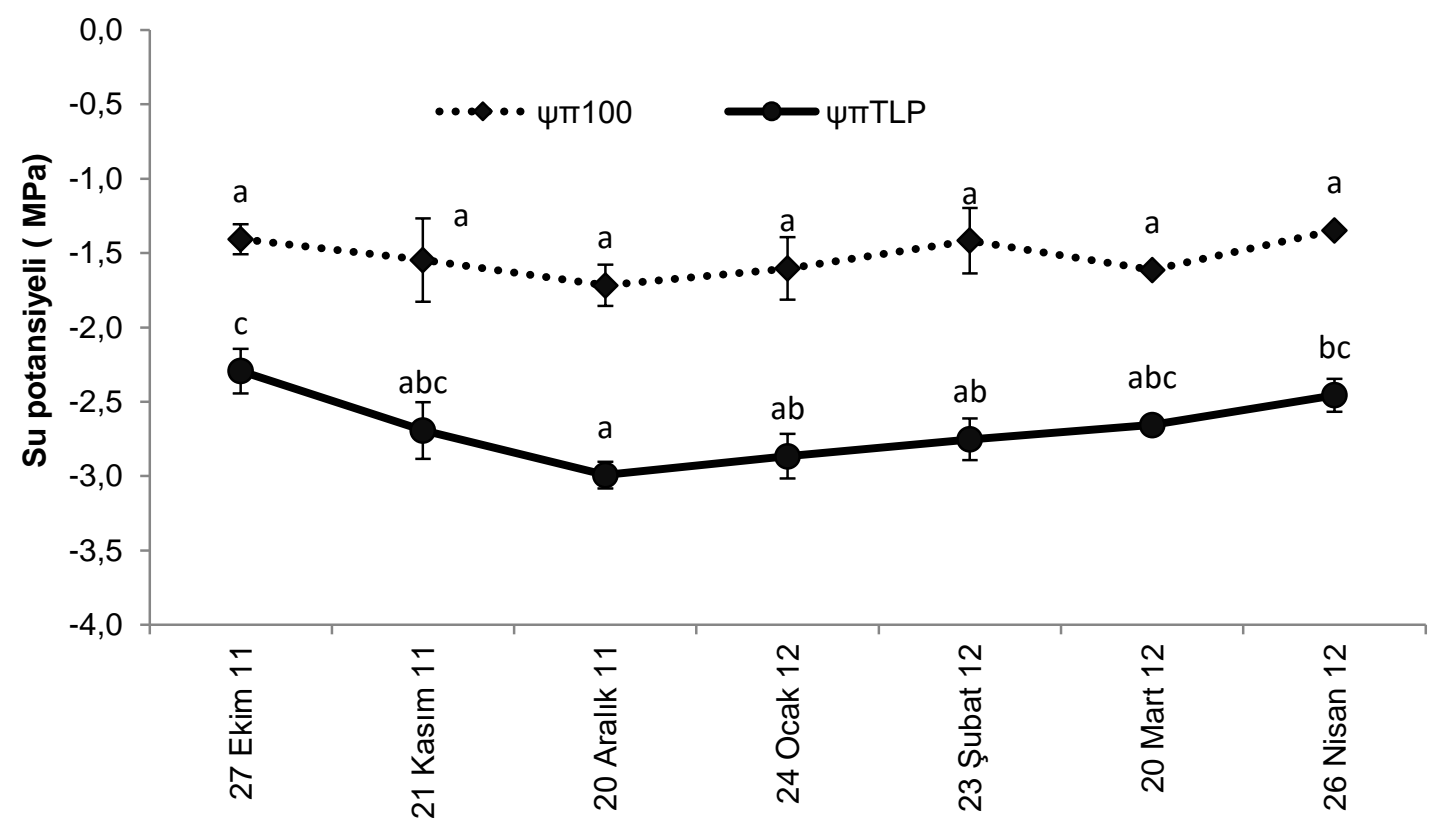

Söküm tarihi

Şekil 2. Doygun haldeki osmotik potansiyel $\left(\psi_{\pi 100}\right)$ ile solma noktasındaki osmotik potansiyelinin $\left(\psi_{\pi L L P}\right)$ mevsimsel değişimi

Doygun haldeki osmotik potansiyel ( $\left.\psi_{\pi 100}\right)$ değerlerine ait varyans analizi sonuçlarına göre, örneklemenin yapıldığ tarihler arasında 0.05 olasilık düzeyinde önemli bir farklılık bulunmamaktadır (Şekil 2). $\psi_{\pi 100}$ ait ortalama değerler incelendiğinde en yüksek değer (-1.35 MPa) 26 Nisan 2012 tarihinde, en düșük değer (-1.72 $\mathrm{MPa})$ ise yine 20 Aralık 2011 tarihinde elde edilmiştir. Ayrıca Şekil 2'i incelendiğinde, $\psi_{\pi 100}$ ile $\psi_{\text {TILP }}$ değerleri yaklaşı paralel seyretmektedir. Sadece $\psi_{\pi 100}$ değeri solma noktasındaki osmotik potansiyelinden ortalama $1.12 \mathrm{MPa}$ daha yüksek değerler almıştır.

$\psi_{\pi 100}$ ile $\quad \psi_{\pi T L P}$ dişındaki diğer su potansiyeli bileşenlerine ait veriler Tablo 1 'de verilmiștir. Buna göre, birim kuru ağırlık başına düşen simplastik su miktarına $(\mathrm{Vo} / \mathrm{DM})$ ait ortalama değerler $0.66 \quad(24$ Ocak 2012) ile $0.89 \quad$ (26 Nisan 2012) arasında, apoplastik su fraksiyonu değerleri ise 0.45 (26 Nisan 2012) ile 0.62 (24 Ocak 2012) arasında değişmektedir. En düşük solma noktasındaki serbest su içeriği değeri (\% 48.53) şubat ayında, en yüksek solma noktasındaki serbest su içeriği değeri $(\%$ 58.04) nisan ayında belirlenmiştir. Solma noktasındaki nispi su içeriği değerleri 77.27 ile 81.71 arasında, RWC değerleri, \% 93.78 (27 Ekim 2011) ile \% 83.00 (20 Mart 2012) arasında değișmektedir. Diğer su potansiyeli bileşenlerinin mevsimsel değişimini belirlemek amaciyla yaptı̆̆ımız varyans analizi sonucunda, $\mathrm{Vo} / \mathrm{DM}, \mathrm{Va} / \mathrm{VT}, \mathrm{FWC}_{\mathrm{TLP}}$, $\mathrm{RWC}_{\mathrm{TLP}}$ ve DWF bakımından örneklemenin yapıldığı tarihler arasında 0.05 önem düzeyinde anlamlı bir fark görülmemiştir. Bununla birlikte RWC bakımından en yüksek değer ekim ayında belirlenirken, diğer aylar arasında istatistiksel anlamda bir farklılık bulunmamaktadır (Tablo 1). 
Tablo 1. Birim kuru ağırlık başına düşen simplastik su miktarı (Vo/DM), apoplastik su fraksiyonu (Va/VT ), solma noktasındaki serbest su içeriği $\left(\mathrm{FWC}_{\mathrm{TLP}}\right)$, solma noktasındaki nispi su içeriği ( $\mathrm{RWC}_{\mathrm{TLP}}$ ), relatif su içeriği (RWC) ve kuru ağırlık oranı (DWF) değerlerine ait

\begin{tabular}{|c|c|c|c|c|c|c|}
\hline Ölçüm tarihi & $\mathrm{Vo} / \mathrm{DM}$ & $\mathrm{Va} / \mathrm{VT}$ & $\mathrm{FWC}_{\mathrm{TLP}}$ & $\mathrm{RWC}_{\mathrm{TLP}}$ & RWC & DWF \\
\hline $\begin{array}{l}27 \text { Ekim } \\
2011\end{array}$ & $0.85 \pm 0.10 \mathrm{a}$ & $0.53 \pm 0.05 a$ & $57.85 \pm 3.26 \mathrm{a}$ & $80.55 \pm 1.59 a$ & $93.78 \pm 0.71 \mathrm{a}$ & $0.35 \pm 0.00 \mathrm{a}$ \\
\hline $\begin{array}{l}21 \text { Kasim } \\
2011\end{array}$ & $0.88 \pm 0.15 a$ & $0.49 \pm 0.07 \mathrm{a}$ & $53.89 \pm 4.50 \mathrm{a}$ & $77.27 \pm 1.58 \mathrm{a}$ & $84.02 \pm 1.95 b$ & $0.37 \pm 0.01 \mathrm{a}$ \\
\hline $\begin{array}{l}20 \text { Aralik } \\
2011\end{array}$ & $0.77 \pm 0.09 \mathrm{a}$ & $0.54 \pm 0.04 \mathrm{a}$ & $53.46 \pm 0.73 \mathrm{a}$ & $78.75 \pm 1.50 \mathrm{a}$ & $87.34 \pm 2.51 \mathrm{~b}$ & $0.37 \pm 0.01 \mathrm{a}$ \\
\hline $\begin{array}{c}24 \text { Ocak } \\
2012\end{array}$ & $0.66 \pm 0.09 a$ & $0.62 \pm 0.04 \mathrm{a}$ & $52.04 \pm 2.46 \mathrm{a}$ & $81.71 \pm 1.21 \mathrm{a}$ & $86.21 \pm 1.18 b$ & $0.37 \pm 0.01 \mathrm{a}$ \\
\hline $\begin{array}{l}23 \text { Şubat } \\
2012\end{array}$ & $0.82 \pm 0.14 \mathrm{a}$ & $0.57 \pm 0.06 \mathrm{a}$ & $48.53 \pm 3.93 \mathrm{a}$ & $78.15 \pm 1.51 \mathrm{a}$ & $85.12 \pm 0.31 b$ & $0.35 \pm 0.01 \mathrm{a}$ \\
\hline $\begin{array}{l}20 \text { Mart } \\
2012\end{array}$ & $0.86 \pm 0.05 a$ & $0.50 \pm 0.02 \mathrm{a}$ & $57.43 \pm 1.86 a$ & $80.08 \pm 2.07 \mathrm{a}$ & $83.00 \pm 5.48 b$ & $0.37 \pm 0.01 \mathrm{a}$ \\
\hline $\begin{array}{l}26 \text { Nisan } \\
2012\end{array}$ & $0.89 \pm 0.02 \mathrm{a}$ & $0.45 \pm 0.01 \mathrm{a}$ & $58.04 \pm 1.91 \mathrm{a}$ & $80.94 \pm 2.49 a$ & $86.26 \pm 0.41 b$ & $0.38 \pm 0.00 \mathrm{a}$ \\
\hline
\end{tabular}

$\mathrm{Su}$ potansiyeli bileşenleri arasındaki ilișkileri belirlemek amaciyla korelasyon analizi yapılmıştır (Tablo 2). Korelasyon analizi sonuçlarına göre; $\psi_{\pi T L P}$ ile $\psi_{\pi 100}(\mathrm{r}=$ $0.76 ; \mathrm{P}<0.01), \quad \psi_{\pi 100}$ ile Vo/DW $(\mathrm{r}=-0.57$; $\mathrm{P}<0.01), \psi_{\pi 100}$ ile $\mathrm{FWC}_{\mathrm{TLP}}(\mathrm{r}=-0.49 ; \mathrm{P}<$
$0.05), \psi_{\pi 100}$ ile $\mathrm{Va} / \mathrm{Vt}(\mathrm{r}=0.51 ; \mathrm{P}<0.05)$ $\mathrm{Vo} / \mathrm{DW}$ ile $\mathrm{RWC}_{\mathrm{TLP}} \quad(\mathrm{r}=-0.59 ; \mathrm{P}<0.01)$, $\mathrm{Vo} / \mathrm{DW}$ ile $\mathrm{FWC}_{\mathrm{TLP}} \quad(\mathrm{r}=0.67 ; \mathrm{P}<0.01)$, Vo/DW ile DWF ( $\mathrm{r}=-0.48 ; \mathrm{P}<0.05)$, $\mathrm{Vo} / \mathrm{DW}$ ile $\mathrm{Va} / \mathrm{Vt} \quad(\mathrm{r}=-0.94 ; \mathrm{P}<0.01)$ arasında önemli ilişkiler belirlenmişsir.

Tablo 2. Su potansiyeli bileşenleri arasındaki ilişkilere ait korelasyon analizi sonuçları

\begin{tabular}{|c|c|c|c|c|c|c|c|c|}
\hline & $\psi_{\pi 100}$ & $\psi_{\pi T L P}$ & Vo/DW & RWC & $\mathrm{RWC}_{\mathrm{TLP}}$ & $\mathrm{FWC}_{\mathrm{TLP}}$ & DWF & $\mathrm{Va} / \mathrm{VT}$ \\
\hline$\psi_{\pi 100}$ & ....... & & & & & & & \\
\hline$\psi_{\pi T L P}$ & $.761 * *$ & ........... & & & & & & \\
\hline Vo/DW & $-.572 * *$ & -.150 & .......... & & & & & \\
\hline RWC & $0.159^{\text {ns }}$ & $0.362^{\mathrm{ns}}$ & -.048 & .......... & & & & \\
\hline $\mathrm{RWC}_{\mathrm{TLP}}$ & $0.35^{\mathrm{ns}}$ & $0.252^{\text {ns }}$ & $-.591 * *$ & $0.138^{\text {ns }}$ & .......... & & & \\
\hline $\mathrm{FWC}_{\text {TLP }}$ & $-.493 *$ & $0.019^{\mathrm{ns}}$ & $.667 * *$ & $0.189^{\mathrm{ns}}$ & $0.062^{\text {ns }}$ & $\ldots \ldots \ldots$ & & \\
\hline DWF & $0.264^{\mathrm{ns}}$ & $0.057^{\mathrm{ns}}$ & $-.478 *$ & $-0.213^{\mathrm{ns}}$ & $0.412^{\mathrm{ns}}$ & $-0.124^{\mathrm{ns}}$ & $\ldots \ldots$ & \\
\hline $\mathrm{Va} / \mathrm{VT}$ & $.515^{*}$ & $0.116^{\mathrm{ns}}$ & $-.943 * *$ & $0.144^{\text {ns }}$ & $.492 *$ & $-.710 * *$ & $0.166^{\mathrm{ns}}$ & ....... \\
\hline
\end{tabular}

Tartışma ve Sonuç

Kokulu ardıç fidanlarında ekim ayından nisan ayına kadar aylık aralıklarla yapılan su potansiyeli ve bileşenlerine ait tespitlerimizde, su potansiyeli bileşenlerinden $\quad \psi_{\pi T L P}$ 'nin ekim ayından başlayarak yavaş yavaş düştüğü ve aralık ayı sonlarında en düşük seviyelerine (-2.99 MPa) ulaştığ 1 tespit edilmiştir. $\psi_{\text {ITLP }}$ değerleri ocak 
ayı sonu itibari ile tekrar yükselişe geçmiş ve nisan ayı sonunda en yüksek değerini alarak, mevsimsel bir değişim göstermiştir. Yürütülen birçok çalışmada da, $\psi_{\text {TILP }}$ 'nin mevsimsel bir değişim gösterdiği belirtilmiştir (Doi et al., 1986; Dirik, 1993; Semerci, 1994; Deligöz, 2011; Deligöz, 2012). Nitekim Dirik (1999), Anadolu karaçamı fidanlarında $\psi_{\pi T L P}$ 'nin kasım ayından başlayarak ocak ayı ortalarına kadar azalarak en düşük seviyesine (-32.78 bar) ulaştığını, şubat ayından itibaren tekrar yükselişe geçerek mart ayında (-26.66 bar) en yüksek seviyeye geldiğini belirlemiştir. Yine Dirik (1991), kızılçamda türünde $\psi_{\pi T L P}$ değerlerinin kış aylarında daha düşük olduğunu tespit etmiştir. Gross ve Koch (1991), Picea abies L. (Karst) türünde bir yıllık sürgünlerdeki $\psi_{\pi L L P}$ 'nin kış sonunda belirgin bir biçimde azaldığını belirlemiştir. Deligöz (2007), Anadolu karaçamı fidanlarında $\psi_{\pi T L P}$ ile $\psi_{\pi 100}$ 'nin mayıs ayından başlayarak kışa doğru gittikçe azalan değerlerinin, hücre içi konsantrasyondaki artıştan, ilkbaharda yükselen değerlerinin ise hücre içi konsantrasyondaki azalıştan kaynaklanmış olabileceğini belirtmiştir.

Çalışmamızda $\quad \psi_{\pi 100}$ değeri $\psi_{\pi T L P}$ değerine paralel bir seyir izlemesine karşın ölçüm dönemleri (ekim-nisan) bakımından istatistiksel olarak anlamlı bir farklılık belirlenmemiştir. Bununla birlikte, $\psi_{\pi 100}$ değeri $\psi_{\text {तILP }}$ 'den ortalama $1.12 \mathrm{MPa}$ daha büyük çıkmıştır. Benzer sonuçlar birçok çalışmada da elde edilmiştir. Örneğin, Dirik (2000), kızılçamda yaptığı çalışmada, $\psi_{\pi 100}$ değeri $\psi_{\pi T L P}$ 'den 1.5 MPar daha büyük bulmuştur. Semerci (2002), Toros sedirinde $\psi_{\pi 100}$ değerinin $\psi_{\pi T L P}$ değerinden yaklaşık olarak 10-15 bar büyük olduğunu belirtmiştir. Corcuera et al. (2002), meşe türlerinde yapmış olduğu çalışmasında, $\psi_{\pi 100}$ ile $\psi_{\text {aTLP }}$ arasında pozitif bir ilişkinin olduğunu belirlemiştir. Kokulu ardıç türü ile yapmış olduğumuz çalışmada da benzer sonuçlara ulaşılmıştır.

Osmotik potansiyel veya diğer doku su ilişkilerindeki mevsimsel değişiminin çiçeklenme, sürgün uzamas1 ve yaprak gelişimini içeren fenolojik olaylarla ilişkili olduğu belirtilmiştir (Tyree et al., 1978; Parker et al., 1982; Kubiske ve Abrams, 1991). Doi et al., (1986), 2 yaşındaki Cryptomeria japonica D. Don. fidanlarında bir y1llık periyot süresince en yüksek osmotik potansiyel $\left(\psi_{\pi 100}\right.$ ile $\left.\psi_{\pi T L P}\right)$ değerlerinin yaprak gelişim periyodunda gerçekleştiğini, en düşük değerlerin ise hava sıcaklılarının en düşük olduğu periyot süresince şubat ortasında tespit edildiğini belirtmiştir. Diğer konifer türlerinde yapılan çalışmalarda ilkbahardaki tomurcuk patlaması ve sürgün uzaması ile ilişkili olarak osmotik potansiyelin yükseldiği bulunmuştur (Tyree et al., 1978, Ritchie ve Schula 1984, Colombo, 1987). Benzer şekilde çalışmamızda mart ve nisan aylarında yaptığımız ölçümlerde $\psi_{\pi 100}$ ile $\psi_{\pi T L P}$ değerlerinin belirgin bir şekilde yükseldiği görülmüştür. Bunun nedeni sicaklıklardaki yükselme ve buna bağlı olarak da gelişme döneminin başlamasıyla açıklanabilir. Nitekim şubat ayında $0{ }^{\circ} \mathrm{C}$ 'nin altında olan sicakl1klar mart $\left(5 \mathrm{C}^{\circ}\right)$ ayından itibaren yükselmeye başlamış ve nisan ayında 12 ${ }^{\circ} \mathrm{C}$ 'ye ulaşmıştır (Şekil 1).

Vo/DW' nın dönemsel değişimi incelendiğinde, genel olarak ekim, kasım, mart ve nisan aylarında yüksek değerler alırken; aralık, ocak ve şubat aylarında düşük değerler aldığı görülmüştür. En düşük (0.66) Vo/DW oran1 24 Ocak 2012 tarihinde, en yüksek oran (0.89) ise 26 Nisan 2012 tarihinde tespit edilmiştir. Va/VT oranındaki dönemsel değişim incelendiğinde ise $\mathrm{Va} / \mathrm{VT}$ 'nın $\mathrm{Vo} / \mathrm{DW}$ oranının tam tersi bir durum sergilediği görülmüştür. En düşük $\mathrm{Va} / \mathrm{VT}$ oran1 26 Nisan $2012(0.45)$ tarihinde en yüksek $\mathrm{Va} / \mathrm{VT} 24$ Ocak 2012 (0.62) tarihinde tespit edilmiştir. Bununla birlikte yapılan varyans analizi sonuçlarında her iki özellik için istatistiksel anlamda ölçüm dönemleri arasında fark belirlenmemiştir. Deligöz (2007)'de, Anadolu karaçamındaki çalışmasında büyümenin devam ettiği 14 Nisan - 26 Mayıs 2004 tarihlerinde Vo/DW'nin yüksek değerler aldığını belirtmiştir. Semerci (1994), ölçüm dönemi boyunca en yüksek Vo/DW oranını mayıs ayında, en düşük oranı ise ocak sonunda 
tespit etmiștir. $\mathrm{Bu}$ oranın, mart sonunda tomurcukların şişmeye başlamasıyla artışa geçtiğini, alt dallarda ve yan sürgünlerdeki tomurcukların patlayip gelişmesiyle en yüksek seviyeye ulaştığını belirtmiştir. Yine Dirik (1999), Vo/DW oranının aralık, ocak ve şubat aylarında en düşük seviyede olduğunu belirlemiş ve bu durumun, hücre içindeki osmotik düzenleme ile birlikte, vakoul içindeki suyunu ksileme aktararak simplastik hacmini küçültmesi ile ilgili olabileceğini belirtmiştir. Nitekim osmotik düzenlemede birim kuru ağırlık başına düşen simplastik su miktarının önemli rolünün olduğu ifade edilmektedir (Doi et al., 1986). Düşük sıcaklıklar karşısında simplastik hacmin azaltılması faydalı olabilir. Nitekim, birçok bitki türünün dondurucu sıcaklıklar sürecinde, soğuğa uyum için simplastik hacim veya turgorun sürdürülmesi için osmotik potansiyellerini düşürdükleri bilinmektedir (Abrams ve Kubiske 1994). Dona duyarlı dokuların su içeriği daima azaltılmaktadir (Gross ve Koch 1991). Gelişme döneminde simplastik su miktarı daha fazla, apoplastik su miktarı ise daha düşüktür. $\mathrm{Bu}$ dönemde fidanlar stres etmenlerine karşı dayanıksızdır. Kış ortasında ise, simplastik su içeriği düşük, apoplastik su içeriği yüksektir. Dolayısıyla fidanlar kış ortasında stres etmenlerine karşı dayanıklı haldedir (Deligöz, 2007). Çalışmamızda ölçüm dönemleri boyunca $\mathrm{RWC}_{\mathrm{TLP}}, \mathrm{FWC}_{\mathrm{TLP}}$ ve DWF değerlerinin istatistiksel anlamda benzer olduğu tespit edilmiş olup, bu özelliklerde mevsimsel bir değişim görülmemiştir. Relatif su içeriği (RWC) bakımından örneklemenin yapıldığ tarihler arasında 0.05 önem düzeyinde anlamlı bir fark bulunmasına karșın gelișme dönemindeki (mart-nisan) RWC değerleri ile kış ortasındaki (aralık-ocak-şubat) RWC değeri benzer bulunmuştur.

Kullanılan fidanlar, genetik ve morfolojik özellikleri açısından ne kadar kaliteli olursa olsun, fizyolojik özellikler bakımından kaliteli değilse, dikim çalışmalarında başarılı olmak mümkün değildir. $\mathrm{Bu}$ bağlamda, çalışmalarda kullanılacak fidanların her şeyden önce stres koşullarına karşı dayanıklı olmas1 gerekmektedir (Deligöz, 2007). Solma noktasındaki su potansiyeli; fidanların tazeliğini düşük ve yüksek sıcaklıklara karș1 dayanıklılıklarını ortaya koyduğu için, onların dikime uygun olup olmadiklarına karar vermede temel kistas kabul edilmektedir (Genç ve Yahyaoğlu, 2007). Deligöz (2007) ve Dirik (1999) tarafindan Anadolu karaçamı türünde yapılan çalışmalarda solma noktasında su potansiyeli değerleri dikkate alınarak uygun söküm ve dikim zamanına ilişkin önerilerde bulunulmuştur. Her iki araştırmacı da solma noktasındaki su potansiyelinin en düşük olduğu kış ortası (aralık - ocak) dönemin söküm-dikim çalışmaları için en uygun zamanın olduğunu belirtmiştir. Çalışmamızda solma noktasında su potansiyeli mevsimsel bir değişim göstermiş ve en düşük değerlerini aralık, ocak ve şubat aylarında yani kış ortasında almıştır. Dolayısıyla aralık, ocak ve şubat döneminde kokulu ardıç fidanların stres etmenlerine dayanıklılığ 1 en üst düzeydedir ve bu dönemler söküm için uygun zamanlardır. Bununla birlikte kokulu ardıç dikim sahalarındaki kar yağışı dikim çalışmalarının gerçekleştirilmesinde önemli bir dezavantaj oluşturmaktadır. Yayılış alanlarında kar erken düşebildiği gibi, geçte kalkabilmektedir (Gültekin ve Gültekin, 2007). Bu durumda dikim mevsimi de oldukça kısalmaktadır. Hava koşullarının uygun olmaması durumunda, fidan sökümlerinin kasım sonuna kadar öne çekilebileceği veya mart sonuna kadar ertelenebileceği söylenebilir. Bununla birlikte, kasım veya mart sonunda sökülen fidanların stres dayanıklılığının aralık, ocak ve şubat sonunda sökülen fidanlara kıyasla daha düşük olacağı da unutulmamalıdır. Diğer taraftan aralık, ocak ve şubat aylarında soğuk saklama da bir seçenek olarak düşünülebilir. Fakat, saklama koşulları ve zamanı konusunda da ayrica bilimsel çalışmalara ihtiyaç bulunmaktadır. IspartaEğirdir Orman Fidanlığı koşullarında, Kokulu ardıç fỉdanları için, ekim ve nisan aylarında kesinlikle fidan sökümleri yapılmamalıdır. Ekim ayında fidanların henüz tam uyku halinde olmamaları, nisan ayında ise gelişme dönemine başlamaları nedeniyle bu dönemler, stres dayanıklılığ açısından oldukça hassas dönemlerdir. Uygun söküm-dikim zamanına karar verirken, solma noktasındaki su potansiyeli 
değerleri bize güvenilir sonuçlar verse de, dikim başarısında etkili olan diğer genetik, morfolojik ve fizyolojik (kök gelişme potansiyeli, uyku hali, beslenme durumu vb) özelliklerin birlikte incelenmesinin daha sağlıklı sonuçlara ulaştıracağı da unutulmamalıdır.

\section{Teşekkür}

$\mathrm{Bu}$ çalışma, S.D.Ü. Fen Bilimleri Enstitüsü, Orman Mühendisliği Anabilim Dalı'nda hazırlanan yüksek lisans tezi kapsamında gerçekleştirilmiştir. Söz konusu yüksek lisans tezi, SDÜ Bilimsel Araştırma Projeleri Yönetim Birimi tarafindan 2870YL-11 nolu proje ile desteklenmiștir. Kurumsal katkılara teşekkür ederiz.

\section{Kaynaklar}

Abrams M. D., Kubiske M. E. 1994. Synchronous changes in tissue water parameters of mature foliage from well-watered and periodically droughted tree seedlings. Journal of Experimental Botany, 45, 171-177.

Anonim, 1987. Türkiye Orman Varlığı. Ormancılık Araştırma Enstitüsü Muhtelif Yayınları, 4, 8 s, Ankara.

Anonim, 2010. Eğirdir Orman Fidanlı̆̆ 1 , 2010-2014 Yilları Fidan Üretim Planı.

Anonim, 2012. Meteoroloji Genel Müdürlüğü. 2011-2012 Yıllarına Ait Aylık Ortalama İklim Verileri.

Colombo S.J. 1987. Changes in osmotic potential, cell elasticity, and turgor relationships of 2nd-year Black spruce container seedlings. Canadian Journal Forest Research, 17, 365-369.

Corcuera L., Camarero J.J., Gil-Pelegrín E. 2002. Functional groups in quercus species derived from the analysis of pressure-volume curves. Trees, 16, 465-472.

Deligöz A., 2007. Anadolu karaçamı [Pinus nigra Arn. Subsp. pallasiana (Lamb.) Holmboe] fidanlarına ait bazı temel morfolojik ve ekofizyolojik özelliklerin dikim başarısına etkisi. Doktora Tezi, Süleyman Demirel Üniversitesi, Fen Bilimleri Enstitüsü, 279 s, Isparta.

Deligöz A. 2011. Seasonal changes in the physiological characteristics of Anatolian black pine and the effect on seedling quality. Turkish Journal of Agriculture and Forestry, 35(1), 23-30.

Deligöz A. 2012. Morphological and physiological differences between bareroot and container Juniperus excelsa seedlings. Turkish Journal of Agriculture and Forestry, 35(5), 619628.
Dirik H. 1991. Kızılçam (Pinus brutia Ten.)'da bazı önemli fidan karakteristikleri ile dikim başarısı arasındaki ilişkiler. Doktora Tezi, İstanbul Üniversitesi, Fen Bilimleri Enstitüsü, $116 \mathrm{~s}$, İstanbul.

Dirik H. 1993. Kızılçam (Pinus brutia Ten.)'da fidan morfolojisinin dikim başarısına etkileri. Uluslararası Kızılçam Sempozyumu (23 Ekim), 348-355, Marmaris, Türkiye.

Dirik H. 1999. Dikim mevsiminde karaçam (Pinus nigra Arn. ssp. pallasiana Lamb. Holmboe.) fidanlarındaki fizyolojik değișiklikler ve bunun dikim başarısı üzerindeki etkileri. İ.Ü. Orman Fakültesi Dergisi, 49A, 59-74.

Dirik H. 2000. Farklı biyoiklim koşullarını temsil eden kızılçam (Pinus brutia ten.) orijinlerinin kurak dönemdeki su potansiyellerinin basınç-hacim (P-V) eğrisi ile analizi. İ.Ü. Orman Fakültesi Dergisi, 50A, 93-103.

Doi K., Morikawa Y., Hinckley T.M. 1986. Seasonal trend of several water relation parameters in Cryptomeria japonica seedlings. Canadian Journal of Forest Research, 16(1), 7477.

Eler Ü., Çetin A. 2006. Ardiç tohumunun çimlendirilme olanakları. Süleyman Demirel Üniversitesi Orman Fakültesi Dergisi, A(1), 3345.

Genç M., 1992. Doğu ladini (Picea orientalis (L.) Link) fidanlarına ait bazı morfolojik ve fizyolojik özelliklerle dikim başarısı arasındaki ilişkiler. Doktora Tezi, KTÜ, Fen Bilimleri Enstitüsü, 272s, Trabzon.

Genç M., Yahyaoğlu Z., 2007. ÜretmeYetiştirme Koşulları ve Etkileri, (Editörler: YAHYAOĞLU, Z. ve M. GENÇ, Fidan Standardizasyonu: Standart Fidan Yetiştirmenin Biyolojik ve Teknik Esasları) Süleyman Demirel Üniversitesi Yayınları, Yayın No: 75, 37-215, Isparta.

Gross K., Konh W. 1991. Water relations of Picea abies. I. Comparasion of water relations parameteres of spruce shoots ezamined at the end of the vegation period and in winter. Physiologia Plantarum, 83, 290-295.

Gültekin H.C. 2007. Ardıç türlerimiz ve fidan üretim teknikleri. Çevre ve Orman Bakanlığı Yayınları, 44 s, İstanbul.

Gültekin H.C., Gültekin U.G. 2006. Bazı Türkiye ardıç türlerinin doğal yayılışları, biyolojisi ve ekolojisi. Batı Akdeniz Ormancılık Araştırma Müdürlüğü Dergisi, 7, 40-66.

Gültekin H.C., Gültekin U.G. 2007. Türkiye'deki ardıç (Juniperus L.) türlerinin silvikültür teknikleri. Doğu Akdeniz Ormancılık Araştırma Müdürlüğü, DOA Dergisi, 13, 69-111.

Kubiske M.E., Abrams M.D. 1991. Seasonal, diurnal and rehydration induced varition of 
pressure-volume relationships in Pseudotsuga menziesii. Physiologia Plantarum, 83, 107-116.

Parker W.C., Pallardy S.G., Hinckley T.M., Teskey R.O. 1982. Seasonal changes in tissue water relations of three woody species of the Quercus-carya forest type. Ecology, 63, 12591267.

Ritchie, G.A. 1984. Assessing Seedling Quality, (eds. DURYEA, M. L. and T.D. LANDIS, Forest Nursery Manual: Production of Bareroot Seedlings) Martinus Nijhoff/Dr. W. Junk. Publishers, 243-259, Hague/Boston/Lancaster.

Ritchie G.A., Schula R.G. 1984. Seasonal changes of tissue-water relations in shoots and root systems of Douglas-fir seedlings. Forest Science, 30, 538-548.

Semerci A. 1994. Doğu ladini (Picea orientalis L. Link.) fidanlarında su potansiyeli bileşenlerinde oluşan dönemsel değişimler. Yüksek Lisans Tezi, Karadeniz Teknik Üniversitesi, Fen Bilimleri Enstitüsü, 82s, Trabzon.

Semerci A. 2002. Sedir (Cedrus libani A. Rich.) fidanlarına ait bazı morfolojik ve fizyolojik karakteristikler ile İç Anadolu'daki dikim başarısı arasındaki ilişkiler. İç Anadolu Ormancılık Araştırma Enstitüsü Yayınları, 142s, Ankara.

Şimşek Y. 1987. Ağaçlandırmalarda kaliteli fidan kullanma sorunları. Ormancılık Araştırma Enstitüsü Dergisi, 33 (1), 7-29.

Tetik M. 1995. Sarıkamış fidanlığında ekim sıklığının sarıçam (Pinus silvestris L.) fidanlarının kalitesine ve dikimdeki başarısına etkileri. Ormancılık Araştırma Enstitüsü Yayınları, Teknik Bülten No: 244, 28 s, Ankara.

Tyree M.T., Cheung Y.N.S., MacGregor M.E., Talbot A.J-B. 1978. The characteristics of seasonal and ontogentic changes in the tissuewater relations of Acer, Populus, Tsuga and Picea. Canadian Journal Forest Research, 56, 635-647.

Yahyaoğlu Z. 1987. Orman ağacı fidanlarının kalite özellikleri, scholander tekniği yardımı ile su potansiyelinin ölçülmesi ve önemi. Karadeniz Teknik Üniversitesi Dergisi, 10(1-2), 140-151. 